\title{
Edupreneurship Pembuatan Kue dan Roti dengan Metode 4 Langkah untuk Memanfaatkan Pangan Potensi Lokal bagi Santri Pondok Pesantren Salafiyah Sulus Salam Balikpapan
}

\section{Farida*1, Henry Winnarko², Tri Retno Nugroho $^{3}$, Nawang Retno Dwiningrum4}

\author{
1,2,4Program Studi Tata Boga, Jurusan Perhotelan, Politeknik Negeri Balikpapan, Indonesia \\ ${ }^{3}$ Program Studi Divisi Kamar, Jurusan Perhotelan, Politeknik Negeri Balikpapan, Indonesia \\ *e-mail: farida@poltekba.ac.id ${ }^{1}$ henry.winnarko@poltekba.ac.id ${ }^{2}{ }^{\text {triretnonugroho@gmail.com }}{ }^{3}{ }_{2}$ \\ nawang.retno@poltekba.ac.id ${ }^{4}$
}

\begin{abstract}
Abstrak
Pondok pesantren Salafiyah Subulus Salam merupakan pesantren yang tetap mempertahankan sistim pembelajaran tradisonal/salaf dan merupakan pondok tahfiz qur'an yang menghasilkan lulusan penghafal penghafal Al qur'an handal. Namun tidak hanya pengetahuan dan ketaqwaan yang harus dimiliki untuk dapat bersaing di dunia nyata setelah lulus sekolah, namun tentunya memiliki pengetahuan, kemampuan dan keterampilan (skill) yang lain juga tidak kalah pentingnya. Dengan memberikan edupreneurship dan pelatihan, selain memberikan semangat entrepreneur juga dibekali dengan kemampuan dan keterampilan (skill) yang nantinya akan membantu kelangsungan hidup setelah lulus sekolah, tidak hanya melakukan dakwah, namun dapat juga berwirausaha dengan kemampuan dan keterampilan yang dimiliki. Tujuan dilaksanakan pengabdian kepada masyarakat bagi santri pondok pesantren Salafiyah Subulus Salam untuk memberikan edupreneurship kepada santriwati pondok pesantren memberikan pengetahuan tentang enterpreneurship untuk membangkitkan semangat wirausaha juga dibekali kemampuan, keterampilan dengan memberikan pelatihan dan memanfaatkan potensi lokal yang mudah didapatkan dengan harga relative murah dan terjangkau, yang ada di kota Balikpapan. Pada pelaksanaan pengabdian masyarakat ini lebih di titik beratkan pada pembuatan kue dan roti dengan menggunakan kangkung sebagai bahan tambahan pada pembuatan kue dan roti dan pada pengolahannya menggunakan peralatan yang sederhana disesuaikan dengan kondisi pondok pesantren. Dengan diberikannya edupreneurship dan pelatihan dapat membangkitkan semangat wirausaha bagi santri pondok pesantren Subulus Salam.
\end{abstract}

Kata kunci: Edupreneurship, Pembuatan Kue dan Roti, Pesantren Salafiyah Subulus Salam

\begin{abstract}
The Salafiyah Subulus Salam Islamic Boarding School is a boarding school that maintains the traditional/salaf learning system and is a tahfiz qur'an boarding school that produces reliable graduates who memorize the Qur'an. However, it is not only knowledge and piety that must be possessed to be able to compete in the real world after graduating from school, but of course having other knowledge, abilities and skills is also important. By providing edupreneurship and training, in addition to providing an entrepreneurial spirit, they are also equipped with abilities and skills that will later help survival after graduating from school, not only doing da'wah, but also entrepreneurship with their abilities and skills. The purpose of community service for the students of the Salafiyah Subulus Salam Islamic boarding school is to provide edupreneurship to the students of the Islamic boarding school, to provide knowledge about entrepreneurship to raise the entrepreneurial spirit, also to be equipped with abilities, skills by providing training and utilizing local potential that is easily obtained at a relatively cheap and affordable price, which is in the city of Balikpapan. In the implementation of this community service, the emphasis is more on making cakes and breads by using kale as an additional ingredient in making cakes and breads and in processing them using simple equipment adapted to the conditions of the Islamic boarding school. By providing edupreneurship and training, it can generate an entrepreneurial spirit for the students of the Subulus Salam Islamic Boarding School.
\end{abstract}

Keywords: Cake and Bread Making, Edupreneurship, Salafiyah Subulus Salam Boarding School

\section{PENDAHULUAN}

Pondok pesantren Salafiyah Subulus Salam adalah salah satu pondok pesantren yang didirikan di beberapa daerah di Indonesia, salah satunya berada di Balikpapan berlokasi di Jalan 
Soekarno Hatta Km 4,5 yang dirintis oleh KH. Muhammad Fadhli sejak tahun 1990, dan kemudian resmi berdiri pada tanggal 17 Juni 1993. Pondok pesantren ini memiliki santri sekitar 164 yang berasal dari Balikpapan dan beberapa daerah di luar Balikpapan. Pondok pesantren ini tetap mempertahankan sistim pembelajaran tradisonal/salaf dan merupakan pondok tahfiz qur'an yang menghasilkan lulusan penghafal penghafal Al qur'an yang handal. Pondok pesantren adalah salah satu lembaga pendidikan yang mempunyai kurikulum tentang ilmu agama, akhlah, kepribadian atau tingkah laku yang baik. Menurut (Akbar, 2019) pendidikan pesantren dapat dikatakan sebagai modal social bagi perkembangan nasional di Indonesia dan berkembang dengan kemandiriannya. Dengan kemandirian yang dimiliki telah dibekali dengan kehandalan pengusaan ilmu agama, teknologi dan ketakwaan. Dalam menghadapi tantang zaman yang semakin berkembang dunia pendidikan khususnya pondok pesantren dihadapkan pada tantangan yang sangat berat, selain menjalankan tugasnya sebagai wadah dalam mendidik manusia, namun harus dapat juga memberikan bekal keterampilan agar dapat menjadi sumber daya yang mampu bersaing dalam kelangsungan hidupnya setelah lulus sekolah. Namun maslah yang sering dihadapi para lulusan yang merupakan sumber daya manusia yang berpendidikan adalah kurangnya kemampuan bersaing dalam dunia kerja.

Hal ini diperkuat oleh Badan Pusat Statistik (BPS) Indonesia pada Februari 2021 yang menerbitkan bahwa Tingkat pengangguran Terbuka (TPT) Februari sebesar 6,26 persen, lapangan pekerjaan yang mengalami peningkatan persentase terbesar adalah sector penyedia akomodasi dan makan minum (0,34 persen poin), sementara sector yang mengalami penurunan terbesar yaitu sector transportasi dan pergudangan (0,30 persen poin). Terdapat 19,10 juta (9,30 persen penduduk usia kerja) yang terdampak COVID-19. Terdiri dari pengangguran karena COVID-19 (1,62 juta orang). Bukan Angkatan Kerja (BAK) karena COVID-19 (0,65 juta orang), sementara tidak bekerja karena COVID-19 (1,11 juta orang) da penduduk bekerja yang mengalami pengangguran jam kerja karena COVID-19 (15,72 juta orang). Dari realita yang terlihat jelas dan nyata saat ini, tidak dapat dipungkiri bahwa angka pengangguran menjadi hal yang sangat memprihatinkan, sehingga sangat perlu mencetak sumber daya manusia yang mempunyai kemampuan dan skill dan berdaya saing.

Kebutuhan akan edupreneurship dan pelatihan tidak dapat ditunda lagi dimana setiap tahun pondok pesantren akan mencetak lulusan yang akan kembali ke masyarakat dan bersaing di dunia nyata. Untuk itu sudah menjadi keharusan dan suatu kebutuhan untuk di implementasikan di dunia pendidikan khususnya di di pondok pesantren Salafiyah Subulus Salam Balikpapan. Dengan memasukkan enterpreneurship di lingkungan pondok pesantren diharapkan nantinya dapat mencetak lulusan yang mempunyai jiwa dan semangat enterpreneurship sehingga nantinya setelah lulus sekolah pola pikir mencari pekerjaan semakin berkurang, tetapi menciptakan lapangan kerja sendiri. Untuk dapat menjadi entrepreneurship yang baik tentunya diperlukan kemampuan dan keterampilan yang mumpuni, sehingga selain mempunyai jiwa dan semangat wirausaha juga mempunyai keahlian. Untuk dapat terampil dibutuhkan pelatihan sehingga mempunyai kompetensi yang memadai.

Menurut (Notoatmodjo, 1998) mengemukakan bahwa: "pelatihan adalah bagian dari suatu proses pendidikan yang tujuannya untuk meningkatkan kemampuan atau keterampilan khusus seseorang atau kelompok orang. Dalam hal ini keterampilan yang diberikan berkaitan dengan pengolahan kue dan roti, yang tentunya membutuhkan pengetahuan dan keterampilan yang baik untuk dapat mengolahnya. Pendapat lain yang mengungkapkan pentingnya pelatihan untuk meningkatkan kemampuan atau keterampilan menurut (Handoko, 1998) pelatihan merupakan suatu upaya untuk mengembangkan sumber daya manusia, terutama untuk mengembangkan kemampuan intelektual, keterampilan dan kepribadian manusia. Dalam dunia pendidikan pelatihan dapat merupakan suatu proses yang dapat dijadikan wahana untuk meningkatkan pengetahuan dan keterampilan bagi siswa dalam memenuhi tuntutan industri selaku pemakai tenaga kerja yang professional. Tujuan pelatihan dan pengembangan personal adalah pertama untuk menutup "gap" antara kecakapan dan kemampuan sesorang dengan permintaan jabatan, diharapkan dapat meningkatkan efisiensi dan efektifitas kerja karyawan dalam mencapai sasaran-sasaran kerja yang telah ditetapkan. Pendapat lain yang menguatkan tentang pelatihan yaitu, (Sudjana, 1993), mengemukakan bahwa: "Metode dan tehnik pelatihan 
untuk penguasaan pengetahuan dan kemampuan praktis peserta pelatihan yang berkaitan dengan dunia kerja dapat menggunakan tehnik pelatihan empat langkah, yaitu (1) to show, (2) to tell, (3) to do dan (4) to check". Oleh karena itu siswa/siswi pondok pesantren juga perlu dibekali dengan kemampuan yang lain sehingga setelah lulus sekolah mereka dapat mengaplikasikan ilmu yang telah didapatkan di dunia nyata atau dengan kata lain mereka kembali ke masyarakat. Dengan diberikan keterampilan tambahan akan dapat lebih mudah menjawab tantangan hidup di masyarakat, termasuk kondidsi yang dialami pada masa sekarang ini, seluruh dunia dilanda pandemik COVID-19, hampir di seluruh penjuru dunia sangat merasakan dampaknya, terutama pada sektor ekonomi yang mengalami penurunan. Salah satu peluang kerja yang dapat memberikan pencerahan yaitu di bidang kuliner, minimal setelah lulus sekolah dapat berwirausaha di bidang kuliner. Namun untuk dapat menekuni bidang kuliner tentunya dibutuhkan keterampilan khusus di bidang kuliner, sehingga mitra meminta dan merasa perlu untuk diberikan pelatihan mengenai pengolahan pastry dan bakery, sebagai langkah awal diberikan pelatihan tentang pembuatan kue dan roti dengan menggunakan potensi lokal yang ada di kota Balikpapan dan menggunakan peralatan yang sederhana. Salah satu potensi lokal yang digunakan sebagai bahan tambahan dalam pembuatan kue dan roti yaitu sayuran kangkung ada di kota Balikpapan yaitu sayuran kangkung yang merupakan sayuran yang mempunyai kandungan gizi yang cukup baik. Sayuran kangkung sendiri merupakan tanaman yang dibudidayakan di kota Balikpapan yang berlokasi di kampung kangkung Kampung Timur (kampung Bejo), yang juga merupakan daerah ekowisata Balikpapan. Dengan dilaksanakan edupreneurship dan pemberian pelatihan pembuatan kue dan roti di pondok pesantrenSalafiyah Subulus Salam Balikpapan akan membantu pemerintah untuk mengurangi angka pengangguran dan menumbuhkan entrepreneur muda yang handal dan mumpuni.

\section{METODE}

Pengabdian kepada masyarakat yang dilakukan oleh tim PKM bersama dengan mitra untuk mengatasi permasalahan yang terjadi dengan metode dan langkah diawali dengan:

1. Observasi lapangan

Observasi lapangan dilakukan dengan tujun untuk mengetahui dan mengumpulkan data terkait potensi, permasalahan, kondisi ponpes dan kurikulum yang ada di pondok pesantren Salafiyah Subulus Salam Balikpapan. Wawancara dan diskusi dilakukan pada pembina dan komite pondok pesantren Salafiyah Subulus Salam.

2. Sosialisasi Program Pelatihan

Pada tahap selanjutnya dilakukan sosialisasi terkait pengabdian yang akan dilaksanakan, mendata peserta yang akan diikutkan pada pelaksnaan pelatihan, mendata dan menyiapkan peralatan dan perlengkapan yang akan digunakan sesuai dengan kondisi ponpes. Sebelum dilaksanakan pelatihan terlebih dahulu dilakukan uji coba resep yang dilakukan di kitchen politeknik negeri Balikpapan pembuatan roti dan kue dengan menambahkan sayuran kangkung sebagai bahan tambahan pada pembuatan kue dan roti sebagai potensi lokal yang ada di kota Balikpapan.

3. Menyiapkan Alat dan Bahan Yang diperlukan

Melakukan pengadaan barang yang tepat dan sesuai dengan kebutuhan dan kondisi pondok pesantren Salafiyah Subulus Salam Balikpapan. Mencari harga yang tepat dan sesuai serta transparant dalam mendukung kegiatan pengabdian masyarakat ini.

4. Pelaksanaan Pelatihan Pembuatan Kue dan Roti

Selanjutnya dilakukan pelatihan dengan dengan 4 langkah yaitu:

a. Pemberian materi mengenai pengetahuan kue dan roti, materi tentang pengetahuan bahan pangan.

b. Pemberian materi mengenai entrepreneurship, membuat laporan harian dan bulanan, pengemasan produk.

c. Pembahasan tentang resep kue dan roti, dan penghitungan harga jual. 
d. Pelatihan pembuatan kue dan roti. Adapun pelatihan yang diberikan yaitu, pembuatan muffin kangkung, choux paste dengan vanilla saus, dan churros. Pelatihan pembuatan aneka roti dengan berbagai bentuk dan isian. Pelatihan dilaksanakan di aula santri putri pondok pesantren Salafiyah Subuls Salam. Setelah dilaksanakan pelatihan, peserta pelatihan diberikan peralatan berupa oven tangkring 2 unit, rolling pin 2 buah, scraper (alat pemotong adonan roti), kuas roti 2 buah. Selanjutnya peserta pelatihan diberikan modal berupa bahan baku yang akan diolah menjadi produk, dan diberikan berupa uang tunai sebagai modal awal. Setelah dilakukan pelatihan dilakukan monitoring untuk

5. Pendampingan melihat perkembangan dari para peserta pelatihan.

Pada tahap ini diberikan pendampingan secara berkelanjutan dan sistematis untuk:

a. Memastikan kualitas produk yang dihasilkan.

b. Memastikan berjalannya kewirausahaan di pondok pesantren Salafiyah Subulus Salam.

c. Memberikan semangat kepada santri untuk terus mengaktifkan kewirausahaan di lingkungan pondok pesantren.

\section{HASIL DAN PEMBAHASAN}

Pengabdian kepada masyarakat yang telah dilakukan adalah upaya untuk berbagi pengetahuan dan ilmu kepada masyarakat dalam dalam bentuk pemberian pengetahuan dan keterampilan serta membangkitkan semangat kewirausahaan bagi santri pondok pesantren Salafiyah Subulus Salam Balikpapan. Sebelum pelaksanaan pengandian terlebih dahulu dilakukan uji coba resep pembuatan kue dan roti dengan penambahan sayur kangkung di kitchen pastry politeknik negeri Balikpapan oleh tim pengabdian dan dibantu oleh 4 (empat) orang mahasiswa tata boga. Uji coba ini perlu dilakukan terlebih dahulu karena tim pengabdian akan menggunakan kangkung sebagai bahan tambahan dalam pembuatan kue sehingga perlu di uji terlebih dahulu ketepatan quantity penggunaan kangkung untuk satu resep. Uji coba dilakukan sebanyak dua kali untuk mendapatkan formulasi yang tepat dan dijadikan sebagai resep acuan pada pelatihan pembuatan kue dan roti, sehingga menghasilkan produk yang layak untuk diproduksi dan diterima oleh konsumen.
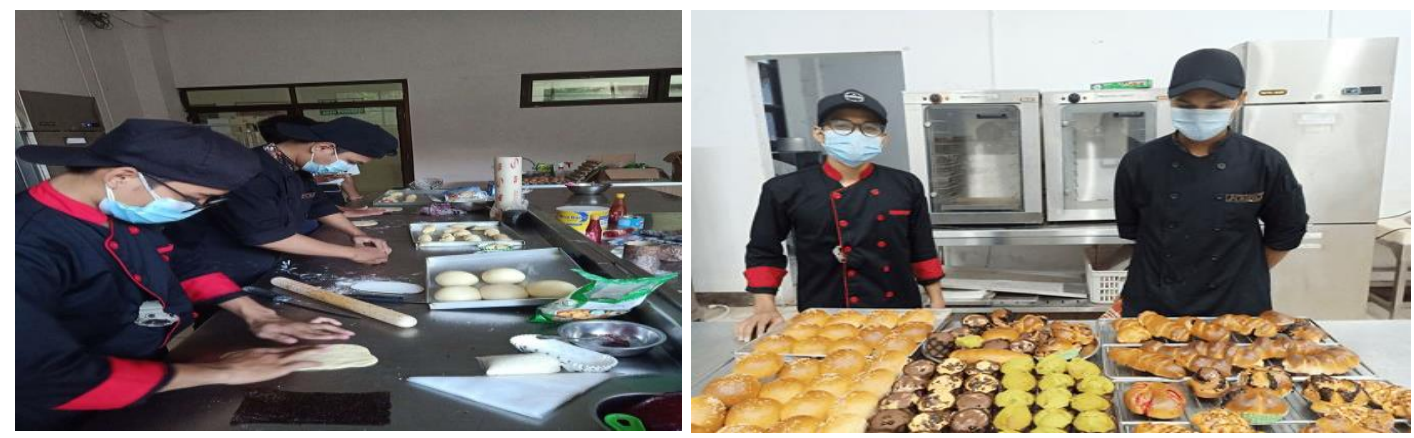

Gambar 1. Uji Coba Resep oleh Tim PKM dan Mahasiswa

Pelaksanaan pengabdian kepada masyarakat dilakukan oleh tim yang beranggotakan 4 orang, kegiatan ini dilaksanakan selama selama 2 hari di pondok pesantren Salafiyah Subulus Salam selama 2 (dua) hari pada tanggal 27-28 Agustus 2021 dengan tetap menerapkan protokol kesehatan COVID-19 dengan menggunakan alat APD lengkap, pengukuran suhu tubuh, dan penggunaan hand sanitizer. Peserta pengabdian kepada masyarakat diikuti sebanyak 20 orang santirwati dan pembina putri. Pelaksanaan pengabdian pada hari pertama diawali dengan pembukaan kegiatan oleh ketua jurusan perhotelan dan dihadiri oleh pembina pondok pesantren Salafiyah Subulus Salam, kemudian dilanjutkan dengan pemberian materi mengenai pengetahuan kue dan roti, pengetahuan bahan pangan oleh ketua tim pengabdian, selanjutnya materi mengenai enterpreneursip, laporan harian dan bulanan, penjelasan resep dan penghitungan harga jual, dan pengemasan produk diberikan oleh anggota tim pengabdian. 
Peserta pelatihan sangat antusias mengikuti pemberian materi dan dilanjutkan dengan sesi tanya jawab, pada sesi ini peserta menanyakan berbagai hal mengenai kue dan roti, bahan makanan, entrerpreneurship, dan pengembangan resep-resep kue dan roti. Pada sesi ini peserta diajarkan bagaimana cara membaca resep, menghitung harga pemakaian bahan, menghitung harga jual per porsi, cara mengemas produk dengan baik sehingga produk yang dihasilkan dapat diterima oleh konsumen, kemudian dilanjutkan cara membuat laporan keuangan (harian dan bulanan).

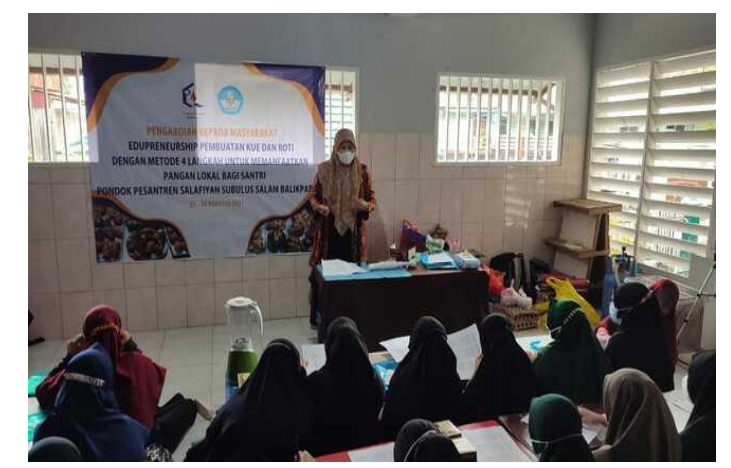

Gambar 2. Pemberian Materi Pengolahan Kue dan Roti

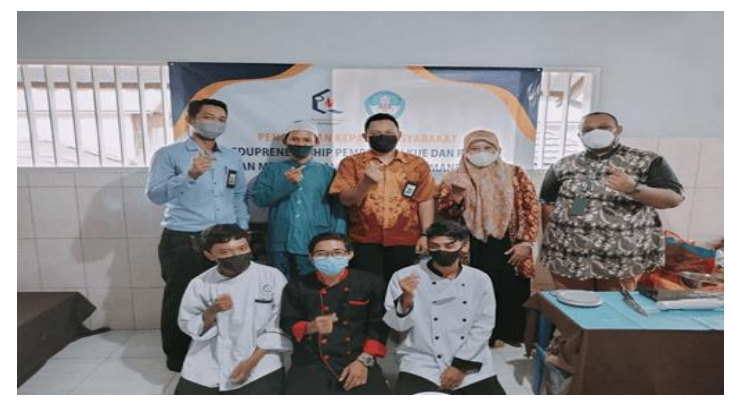

Gambar 3. Tim Pengabdian Kepada Masyarakat dan Pembinan Pondok Pesantren Salafiyah Subulus Salam Balikpapan

Pelaksanaan pengabdian kepada masyarakat pada hari kedua dilanjutkan dengan pelatihan pembuatan kue dan roti jenis pelatihan kue yang diberikan yaitu, pebuatan muffin, choux paste, churros, kemudian pada pembuatan roti diberikan pelatihan cara membuat roti dengan berbagai bentuk dan isian yang sangat menarik. Pada pelaksaan pelatihan peserta sangat antusias mengikuti pelatihan dan para peserta diberikan kesempatan untuk membuat, membentuk, memanggang, dan mengemas kue dan roti.

Setelah diberikan pelatihan peserta dibagi menjadi 2 kelompok wirausaha dimana setiap kelompok ini yang akan bertugas secara bergiliran membuat produk dengan menggunakan bahan bakudan peralatan yang telah diberikan sebagai modal usaha. Selanjutnya dilakukan pendampingan selama 4 minggu untuk melihat perkembangan wirausaha yang dilaksanan. Pendampingan pertama dilaksanakan pada tanggal 3 Agustus 2021 santri yang telah diberikan pelatihan sudah mulai membuat produk dan menjualnya di lingkungan santriwati. Monitoring ke 2 dilaksanakan pada tanggal 10 September 2021, monitoring ke 3 dilaksanakan pada tanggal 17 September 2021, dan monitoring ke 4 dilaksanakan pada tanggal 24 September 2021. Dari hasil monitoring yang dilakukan hasil penjualan produk peserta pelatihan semakin meningkat dan kemampuan membuat kue dan roti juga semakin meningkat dan dapat mengembangkan produk yang telah diberikan slah satu dari pengembangan produk yang telah dibuat dan dijual oleh santri yang telah mengikuti pelatihan yaitu mereka sudah mampu mengembangkan dari produk yang telah dilahtikan dengan membuat bolu kukus, donat, dan resoles mayo. 

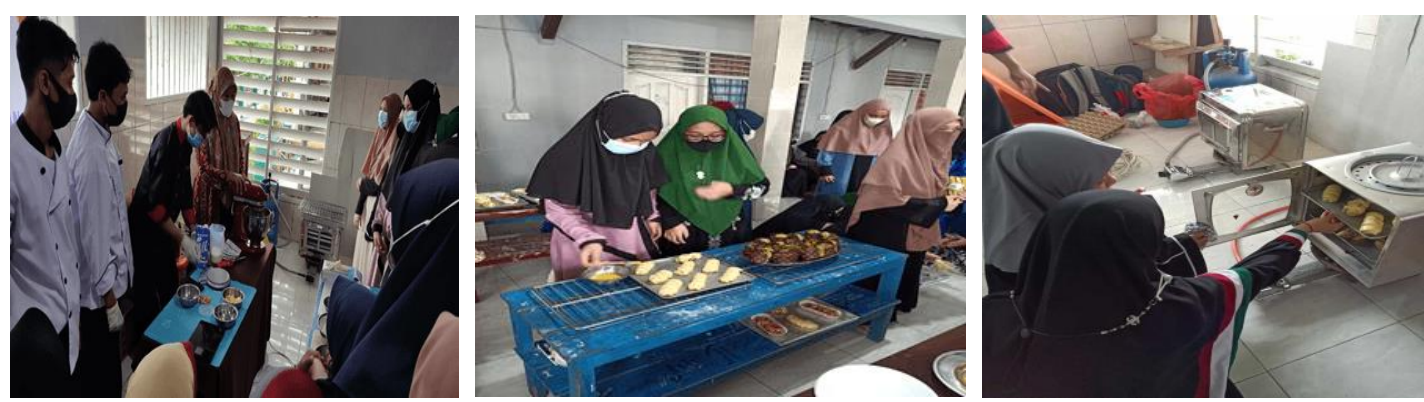

Gambar 4. Kegiatan Pembuatan Kue dan Roti
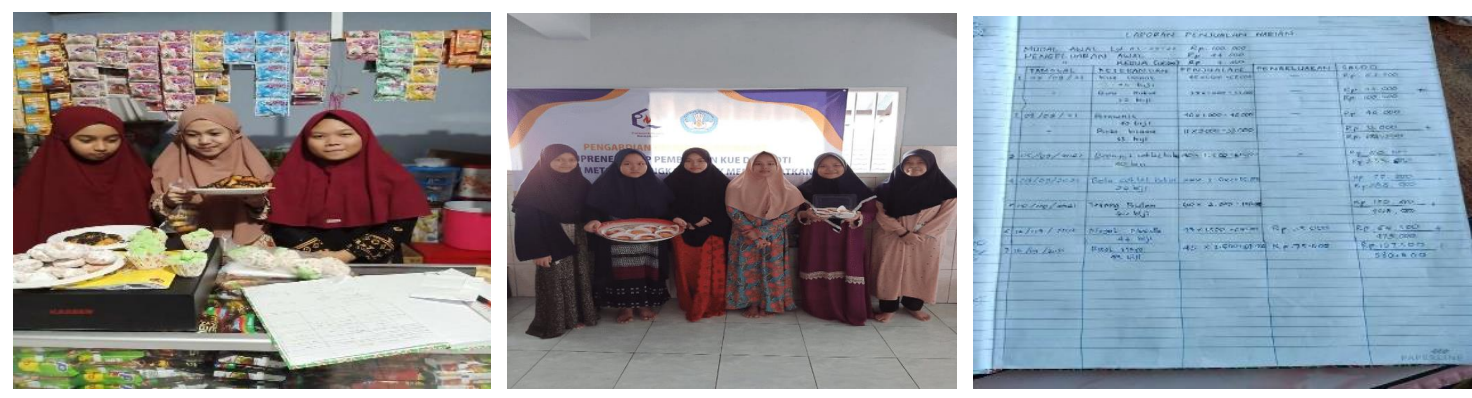

Gambar 5. Kegiatan Pendampingan dan Monitoring

\section{KESIMPULAN}

Pelaksanaan pengabdian kepada masyarakat dengan memberikan pengetahuan dan, keterampilan dan menumbuhkan semangat entrepreneurship pada santriwati pondok pesantren Salafiyah Subulus Salam, memberikan hasil yang sangat positif dalam hal pembuatan kue dan roti, serta dapat menumbuhkan semangat jiwa wirausaha sehingga keterampilan santriwati ponpes dapat selalu di asah dan lebih ditingkatkan lagi.

\section{UCAPAN TERIMA KASIH}

Penulis mengucapkan terima kasih kepada P3M Politeknik Negeri Balikpapa yang telah memberi dukungan financial terhadap kegiatan pengabdian pengabdian kepada masyarakat ini ini.

\section{DAFTAR PUSTAKA}

Akbar, Muna. (2019). Kompetensi Pedagogik Ustadz Di Pondok Pesantren Darussalam Sumbersari Kencong Kepung. Jurnal Pendidikan dan Studi Keislaman. https://ejournal.iaitribakti.ac.id/index.php/intelektual/index Volume 9, Nomor 1, April 2019

Boy. (2011). menyoal pengangguran terbuka. Blogspot.com: boyyenratamin.

Bukit. (2014). Strategi dan Inovasi Oendidikan Kejuruan dari Kompetensi Ke Kompetensi. Bandung: Alfabeta.

Habiburrahman. (2018). Model Edupreneurship di Pesantren Salaf (Studi Kasus Di Pondok Pesantren Nurul Hidayah). Bandung: Universitas Islam Sunan Kalijaga Yogyakarta.

Mulyasa. (2003). Kurikulum Berbasis Kompetensi. Bandung: PT. Remaja Rosdakarya.

Mustofa. (2010). Model Pendidikan dan Pelatihan (Konsep Aplikasi). Bandung: Alfabeta.

Kemenkes RI, 2018. Hasil Provinsi Utama Riskesdas (2018) kalimantan Barat. Has. Provinsi Utama Riskesdas 20-21. 